\title{
Emended descriptions of Tilletiopsis washingtonensis, Tilletiopsis cremea and Tilletiopsis lilacina
}

\author{
Makiko Hamamoto, Miki Tamura and Takashi Nakase
}

Japan Collection of Microorganisms, The Institute of Physical and Chemical Research (RIKEN), Wako, Saitama 351-0198, Japan

\author{
Author for correspondence: Makiko Hamamoto. Tel: +8148467 9560. Fax: +81484624617 \\ e-mail: hamamoto@jcm.riken.go.jp
}

Keywords: Tilletiopsis washingtonensis, Tilletiopsis cremea, Tilletiopsis lilacina, Tilletiopsis, ballistoconidia-forming fungi

\section{INTRODUCTION}

The genus Tilletiopsis was suggested by Derx in 1930 for a ballistoconidia-forming fungus without budding cells and a Latin diagnosis was provided for Tilletiopsis 'sp. 4' as the type for this genus (Derx, 1948). However, this strain is no longer available. In 1950, Nyland described two species, Tilletiopsis minor and Tilletiopsis washingtonensis, and chose the latter species as the neotype for the genus Tilletiopsis. Tubaki (1952) described two new species, Tilletiopsis cremea and Tilletiopsis lilacina, as well as a variety of $T$. minor ( $T$. minor var. flava), according to the consistency of colonies and the sizes of ballistoconidia. Gokhale (1972) made a comparative study of the assimilation of certain carbon and nitrogen compounds and of some other physiological properties, described three new

Abbreviation: ITS, internal transcribed spacer.

The DDBJ accession numbers for the internal transcribed spacer sequences are given in Table 1. species (Tilletiopsis albescens, Tilletiopsis fulvescens and Tilletiopsis pallescens) and proposed a key for the identification of the species of the genus based on their physiological and morphological characters. Yamazaki et al. (1985) studied the nutritional physiology and electrophoretic patterns of 10 enzymes of 17 strains in the genus Tilletiopsis. They concluded that $T$. albescens, T. cremea, T. fulvescens, T. lilacina, T. minor var. flava, T. minor var. minor, T. pallescens and $T$. washingtonensis were distinct species, but did not formally propose a species name for $T$. minor var. flava. Recently, Boekhout (1991) proposed that $T$. minor var. flava should be a separate species, i.e. $T$. flava (Tubaki) Boekhout comb. nov., on the basis of nutritional physiology, electrophoretic karyotype and nuclear base composition (Boekhout et al., 1992a, b), in addition to the electrophoretic enzyme patterns described earlier (Yamazaki et al., 1985). Moreover, Boekhout (1991) considered that T. washingtonensis, $T$. cremea and T. lilacina were conspecific according to the morphological, physiological and biochemical similarities, in spite of the low similarities of their electrophoretic enzyme patterns (Yamazaki et al., 
1985) and the considerable heterogeneity of their karyotype patterns (Boekhout et al., 1992a).

To define the taxonomic status of $T$. washingtonensis, $T$. cremea and $T$. lilacina, we investigated nuclear DNA base composition, DNA relatedness and internal transcribed spacer (ITS) regions among the strains in the 'washingtonensis group'. This included the three type strains and nine strains previously identified as any one of the three species.

\section{METHODS}

Strains used in this study. Twelve strains of the "washingtonensis group' used in this study were obtained from JCM (Japan Collection of Microorganisms, Saitama, Japan) (Table 1). All strains were grown at $17^{\circ} \mathrm{C}$ in yeast extract/ malt extract broth or on yeast extract/malt extract agar (Difco).

Assimilation test of carbon and nitrogen compounds. Assimilation of carbon compounds was assessed with the method currently used in yeast taxonomy (van der Walt \& Yarrow, 1984). Assimilation of nitrogen compounds was examined on solid media with starved inoculum, as described by Nakase \& Suzuki (1986).

Determination of DNA base composition and DNA relatedness. DNA isolation, the determination of $\mathrm{G}+\mathrm{C}$ content and DNA-DNA reassociation experiments were carried out as described previously (Hamamoto \& Nakase, 1995).

Nucleotide sequence analyses of ITS regions. DNA extraction for the PCR was achieved as described in the following. One loop of cells was suspended in an equal volume of extraction buffer $(200 \mathrm{mM}$ Tris $/ \mathrm{HCl}, \mathrm{pH} 8 \cdot 5$,
$250 \mathrm{mM} \mathrm{NaCl}, 25 \mathrm{mM}$ EDTA, $0.5 \%$ SDS, w/v) and one spoonful of aluminium oxide $(50-70 \mathrm{mg})$. The suspended cells were disrupted by pestle (Kontes) on ice for 1-2 min. An equal volume of phenol saturated with TE buffer $(10 \mathrm{mM}$ Tris/HCl, $\mathrm{pH} 7 \cdot 6,1 \mathrm{mM}$ EDTA, $\mathrm{pH}$ 8.0): chloroform (1:1, $\mathrm{v} / \mathrm{v}$ ) was added to the broken-cell suspension and mixed well. Following centrifugation, the aqueous upper layer was transferred to a new microtube. Nucleic acids were precipitated from the aqueous phase with $0 \cdot 1$ vol. $3 \mathrm{M}$ sodium acetate (pH 5.2) and 2 vols 2-propanol held at $-80^{\circ} \mathrm{C}$ for $10 \mathrm{~min}$. Nucleic acids were recovered by centrifugation. The primers used for amplification and sequencing of the ITS region were those described by White et al. (1990). The PCR products were sequenced using an ABI Prism BigDye Terminator Cycle Sequencing Ready Reaction Kit (Applied Biosystems). Analyses of DNA sequence reactions were performed with an Applied Biosystems model 310 sequencer. Sequences were aligned using CLUSTAL $w$ version 1.75 (Thompson et al., 1994) and were manually adjusted. Evolutionary distances were calculated using the PHYLIP version $3.57 \mathrm{c}$ program DNADIST (Felsenstein, 1995) with Kimura's two-parameter model; trees were constructed in NEIGHBOR by the neighbour-joining method (Saitou \& Nei, 1987). The confidence values of branches were determined by performing a bootstrap analysis (Felsenstein, 1985) with 1000 replicates.

The sequences determined were deposited in the DDBJ database under the accession numbers shown in Table 1.

\section{RESULTS}

\section{Physiological properties}

We examined 12 strains of the 'washingtonensis group' for the assimilation of 36 carbon compounds and five nitrogen compounds. The assimilation pat-

Table 1. Strains of Tilletiopsis used in this study

\begin{tabular}{|c|c|c|c|}
\hline $\begin{array}{l}\text { JCM } \\
\text { no. }\end{array}$ & Other designation(s)* & Original denomination & $\begin{array}{l}\text { ITS sequence } \\
\text { accession no. }\end{array}$ \\
\hline 2899 & & T. lilacina (T. Nakase, unpublished data, 1986) & AB025683 \\
\hline $5184^{\mathrm{T}}$ & $\begin{array}{c}\text { CBS } 605.83^{\mathrm{T}}, \text { IFO } \\
6831^{\mathrm{T}}, \text { YK } 804\end{array}$ & Type strain of $T$. cremea (Tubaki, 1952) & AB025690 \\
\hline $5188^{\mathrm{T}}$ & $\begin{array}{l}\text { CBS } 435.92^{\mathrm{T}}, \text { CBS } \\
603.83^{\mathrm{T}}, \text { IFO } 6832^{\mathrm{T}}, \\
\text { YK } 811\end{array}$ & Type strain of $T$. lilacina (Tubaki, 1952) & AB025679 \\
\hline 5189 & YK 812 & T. lilacina (Yamazaki et al., 1985) & AB025684 \\
\hline 5190 & YK 816 & T. lilacina (Yamazaki et al., 1985) & AB025685 \\
\hline 5289 & & T. lilacina (T. Nakase, unpublished results, 1986) & AB025680 \\
\hline 5736 & & T. lilacina (T. Nakase, unpublished results, 1986) & AB025681 \\
\hline 7482 & NB 209 & T. lilacina (T. Nakase, unpublished results, 1986) & AB025687 \\
\hline 7494 & & T. lilacina (T. Nakase, unpublished results, 1986) & AB025688 \\
\hline $8362^{\mathrm{T}}$ & $\begin{array}{c}\text { ATCC } 36489^{\mathrm{T}}, \text { CBS } \\
544.50^{\mathrm{T}}, \text { YK } 803\end{array}$ & Type strain of $T$. washingtonensis (Nyland, 1950) & AB025686 \\
\hline 8501 & CBS 358.86, YK 815 & T. lilacina (Yamazaki et al., 1985) & AB025682 \\
\hline 8502 & CBS 359.86, YK 817 & T. lilacina (Yamazaki et al., 1985) & AB025689 \\
\hline
\end{tabular}

* ATCC, American Type Culture Collection (Manassas, VA, USA); CBS, Centraalbureau voor Schimmelcultures (Baarn and Delft, The Netherlands); IFO, Institute for Fermentation (Osaka, Japan); NB, used by T. Nakase (unpublished data) and Boekhout (1991); YK, used by Yamazaki et al. (1985) and Boekhout (1991). 
Table 2. DNA base composition and relatedness among Tilletiopsis strains

\begin{tabular}{|c|c|c|c|c|c|c|c|}
\hline \multirow[t]{2}{*}{ Species } & \multirow[t]{2}{*}{ Strain } & \multirow{2}{*}{$\begin{array}{c}G+C \\
\text { content } \\
(\mathrm{mol} \%)\end{array}$} & \multicolumn{5}{|c|}{ Percentage relative binding of DNA from: } \\
\hline & & & $\begin{array}{l}\text { JCM } \\
\mathbf{8 3 6 2}^{\mathrm{T}}\end{array}$ & $\begin{array}{r}\text { JCM } \\
7482\end{array}$ & $\begin{array}{l}\text { JCM } \\
\mathbf{5 1 8 4}^{\mathrm{T}}\end{array}$ & $\begin{array}{l}\text { JCM } \\
\mathbf{5 1 8 8}^{\mathrm{T}}\end{array}$ & $\begin{array}{r}\text { JCM } \\
5189\end{array}$ \\
\hline T. washingtonensis & JCM $8362^{\mathrm{T}}$ & 66 & 100 & 87 & 27 & 22 & 34 \\
\hline Tilletiopsis sp. & JCM 7482 & 67 & 84 & 100 & 35 & 31 & 40 \\
\hline T. cremea & $\mathrm{JCM} 5184^{\mathrm{T}}$ & 67 & 28 & 26 & 100 & 16 & 27 \\
\hline T. lilacina & JCM $5188^{\mathrm{T}}$ & 67 & 39 & 19 & 25 & 100 & 100 \\
\hline Tilletiopsis sp. & JCM 5189 & 67 & 22 & 24 & 28 & 77 & 100 \\
\hline
\end{tabular}

terns are almost the same across the 12 strains tested and are outlined in the emended descriptions below.

\section{DNA base composition}

The $\mathrm{G}+\mathrm{C}$ contents of the DNA of the type strains of $T$. washingtonensis, T. cremea and T. lilacina were 66, 67 and $67 \mathrm{~mol} \%$, respectively. The values for the other nine strains of the 'washingtonensis group' ranged from 67 to $68 \mathrm{~mol} \%$ : the value for strains JCM 2899 , JCM 5190, JCM 5289, JCM 5736, JCM 7494, JCM 8501 and JCM 8502 was $68 \mathrm{~mol} \%$ while that for strains JCM 5189 and JCM 7482 was $67 \mathrm{~mol} \%$.

\section{DNA-DNA hybridization among strains of $T$. washingtonensis, $T$. cremea and T. lilacina and two strains of the 'washingtonensis group'}

Table 2 shows the levels of DNA complementarity among the type strains of $T$. washingtonensis, $T$. cremea and T. lilacina and strains JCM 5189 and JCM 7482. The degrees of interspecific relative binding among the type strains of $T$. washingtonensis, $T$. cremea and $T$. lilacina ranged from 16 to $39 \%$. Strain JCM 5189 showed high degrees of relative binding (77-100\%) with the type strain of $T$. lilacina JCM $5188^{\mathrm{T}}$, but low degrees (22-34\%) with the type strains of $T$. washingtonensis and T. cremea. Strain JCM 7482 showed high degrees of relative binding (84-87\%) with the type strain of $T$. washingtonensis, but low degrees (19-35 $\%$ ) with the type strains of $T$. cremea and T. lilacina. It was intended that strain JCM 10447, originally identified as T. cremea by Hoog and Boekhout [from the database of the Centraalbureau voor Schimmelcultures (CBS) Baarn/Delft, The Netherlands], would be tested. However, strain JCM 10447 was not included in the DNA-DNA reassociation experiments in this study because it had a $\mathrm{G}+\mathrm{C}$ value of $58 \mathrm{~mol} \%$, which clearly showed it to be different from the type strains of the three species ( $T$. washingtonensis, $T$. cremea and $T$. lilacina, which have $\mathrm{G}+\mathrm{C}$ values of $66-67 \mathrm{~mol} \%$ ).

\section{Phylogenetic analysis}

The nucleotide sequences of ITS regions (ITS1 and ITS2) of the 12 strains shown in Table 1 were determined and analysed. The trees in Fig. 1 were

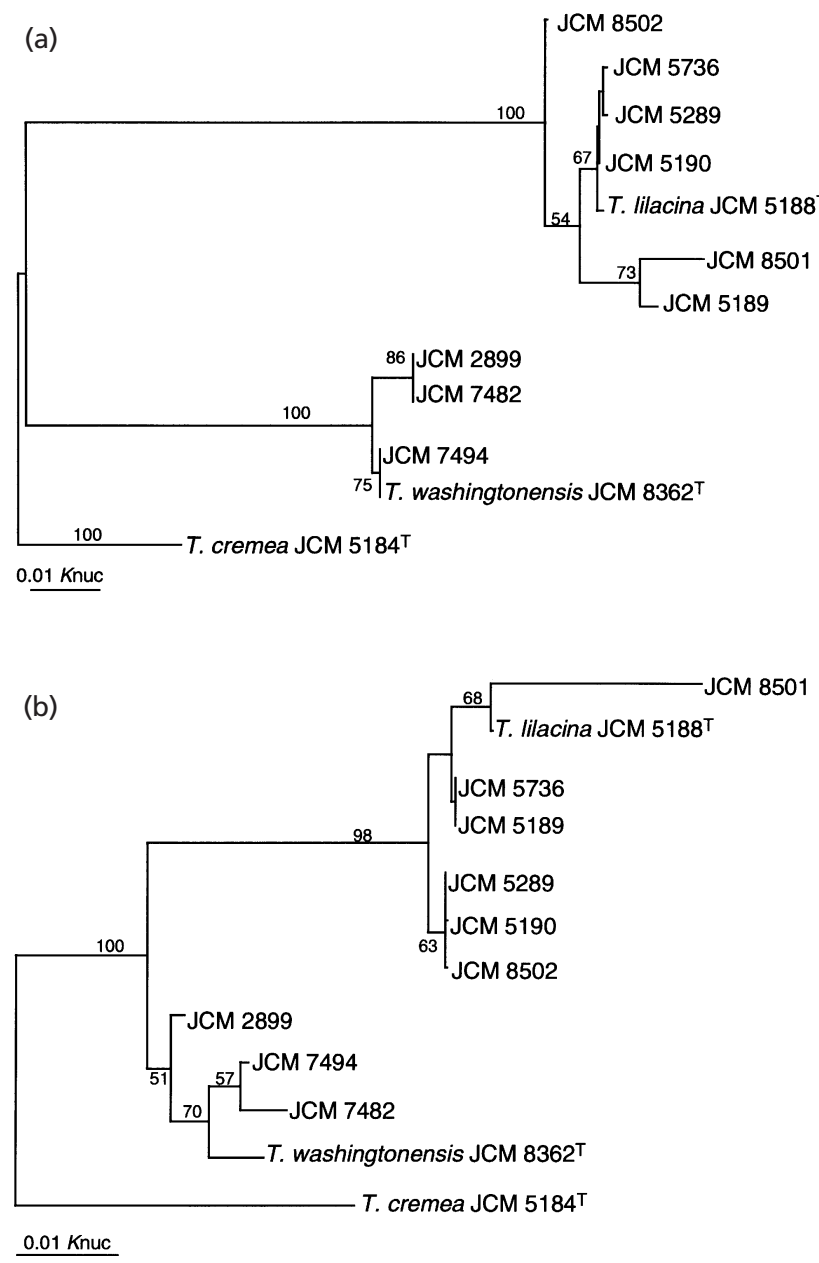

Fig. 1. Phylogenetic relationships among strains of the 'washingtonensis group'. The trees were constructed from the evolutionary distance data for ITS1 (a) and ITS2 (b) as described in the text. Numbers by the nodes are bootstrap frequencies (values $<50 \%$ are not shown) derived from 1000 replicates. Bars, $0.01 K_{\text {nuc }}$.

constructed from the data sets aligned by CLUSTAL $\mathrm{W}$ version 1.75 on 156 ITS1 (Fig. 1a) and 259 ITS2 (Fig. $1 \mathrm{~b})$ sites. On the basis of the analysis, the strains were clearly divided into three clusters. The type strain of $T$. washingtonensis $\left(\mathrm{JCM} 8362^{\mathrm{T}}\right)$, strains JCM 2899, JCM 
7482 and JCM 7494 formed a tight phylogenetic cluster in the ITS1 tree. The type strain of T. lilacina (JCM $5188^{\mathrm{T}}$ ) and strains JCM 5189, JCM 5190, JCM 5289, JCM 5736, JCM 8501 and JCM 8502 formed a tight phylogenetic cluster in both the ITS1 and the ITS2 tree. The type strain of $T$. cremea (JCM $5184^{\mathrm{T}}$ ) was placed independently in both the ITS1 and the ITS2 tree.

\section{DISCUSSION}

\section{Relationships among T. washingtonensis, T. cremea} and T. lilacina

The differences in the $\mathrm{G}+\mathrm{C}$ contents among the type strains of $T$. washingtonensis, $T$. cremea and T. lilacina and the other nine strains of the 'washingtonensis group' examined in this study (within $2 \mathrm{~mol} \%$ ) were not significant enough to discriminate yeast species. This result is consistent with the result reported by Boekhout et al. (1992a).

As shown in Table 2, the low levels of DNA complementarity among the type strains of $T$. washingtonensis, $T$. creme $a$ and $T$. lilacina indicate that the three species should be treated as distinct species, as suggested by Yamazaki et al. (1985). In this study, strain JCM 5189, which has been identified as T. lilacina mainly on the basis of its electrophoretic enzyme patterns (Yamazaki et al., 1985), was confirmed as T. lilacina from the high levels of DNA reassociation values with the type strain of T. lilacina. In addition, JCM 7482, which had been identified as T. lilacina on the basis of its physiological similarities to the type strain of T. lilacina (T. Nakase, unpublished results, 1986), was identified as T. washingtonensis from the high levels of DNA reassociation with the type strain of T. washingtonensis, as discussed in the next section (Physiological properties).

The ITS region has been found to be useful in resolving relationships among close taxa, because of its high substitution rate compared with that of $18 \mathrm{~S}$ and $26 \mathrm{~S}$ rDNA (Berbee et al., 1995; Waalwijk et al., 1996; James et al., 1996; Oda et al., 1997; Nagahama et al., 1999). To clarify the relationships within strains of the 'washingtonensis group' at the species level, the sequences of ITS1 and ITS2 among the 12 strains, including the type strains of $T$. washingtonensis, $T$. creme $a$ and $T$. lilacina, were determined and analysed. The trees derived from ITS1 and ITS2 placed the five strains [clearly separated into three distinct species, i.e. T. washingtonensis (strains JCM 7482 and JCM $8362^{\mathrm{T}}$ ), $T$. cremea (strain JCM 5184 ${ }^{\mathrm{T}}$ ) and T. lilacina (strains JCM $5188^{\mathrm{T}}$ and JCM 5189) based on the DNA complementarity in this study] into each species. From the result, it is clear that the three clusters in the ITS trees correspond with the three species, that strains JCM 2899 and JCM 7494 should be treated as $T$. washingtonensis and that strains JCM 5190, JCM 5289, JCM 5736, JCM 8501 and JCM 8502 should be treated as $T$. lilacina. Some differences in the topologies between the ITS1 and ITS2 trees may reflect the higher evolutionary rates of ITS1 relative to those of ITS2 (James et al., 1996).

\section{Physiological properties}

We compared the results of carbon- and nitrogenassimilation tests from this study with those of Boekhout (1991), T. Nakase (unpublished results, 1986) and Yamazaki et al. (1985). The results for some carbon and nitrogen compounds differ between studies. For example, strain JCM 7482 (originally from strain NB 209 by T. Nakase) assimilated galactose, cellobiose, D-arabinose, ethanol and L-lysine in this study and that of Boekhout (1991) but did not do so in the study by T. Nakase (unpublished results, 1986). Strain JCM 8502 (originally from strain YK $817=$ KG-3 by Yamazaki et al., 1985) assimilated melibiose, DL-lactic acid and L-lysine in this study and in that of Boekhout (1991) but did not do so in the study by Yamazaki et al. (1985). A number of other differences were found. Differences in assimilation patterns for some carbon and nitrogen compounds in this study, by Boekhout (1991) and Yamazaki et al. (1985) were also observed for strains JCM 5184 (originally from NI 3113 by Tubaki, 1952), JCM 5188 ${ }^{\mathrm{T}}$ (originally from NI 3114 by Tubaki, 1952) and JCM 5189 (originally from No. 84 by M. Yoshizawa) (data not shown). These differences might have been caused by difficulties in judging the assimilation reactions of some compounds. This indicates that the assimilation pattern of carbon and nitrogen compounds is not a sufficiently good criterion for species delimitation in the genus Tilletiopsis and that species identification without molecular biological data are highly unreliable.

In The Yeasts, a Taxonomic Study, Boekhout concluded that $T$. washingtonensis, $T$. cremea and $T$. lilacina were considered conspecific on the basis of morphological, physiological and biochemical similarities (Boekhout, 1998); however, T. cremea and $T$. lilacina were revealed as distinct species in this study. Consequently, we propose the emendation of Tilletiopsis washingtonensis Nyland, Tilletiopsis cremea Tubaki and Tilletiopsis lilacina Tubaki, as outlined below. A total of eight species, T. albescens Gokhale, $T$. cremea (Tubaki) Hamamoto \& Nakase, T. flava (Tubaki) Boekhout, T. fulvescens Gokhale, T. lilacina (Tubaki) Hamamoto \& Nakase, $T$. minor Nyland, $T$. pallescens Gokhale and T. washingtonensis (Nyland) Hamamoto \& Nakase, should be accepted in the genus Tilletiopsis.

\section{Emended description of Tilletiopsis washingtonensis Nyland}

Characteristics additional to the description of Nyland 1950 of this species are given below.

Assimilates D-glucose, galactose (variable), L-sorbose (variable), sucrose, maltose, cellobiose (variable), trehalose, melibiose (variable), raffinose, melezitose, soluble starch, D-xylose, L-arabinose, D-arabinose (vari- 
able), D-ribose, ethanol (variable), glycerol, erythritol, ribitol (variable), D-mannitol, D-glucitol, glucono- $\delta$ lactone, DL-lactic acid (variable), succinic acid and citric acid. Does not assimilate lactose, inulin, Lrhamnose, galactitol, methyl $\alpha$-D-glucoside, salicin, 2ketogluconic acid, 5-ketogluconic acid, inositol and D-glucuronic acid. Assimilates nitrate, nitrite and Llysine (variable). Does not assimilate ethylamine or cadaverine. Growth does not occur in vitamin-free medium. Thiamin is required for growth. Growth does not occur on $50 \%(\mathrm{w} / \mathrm{w})$ glucose/yeast extract agar. No starch-like substance is produced. Xylose is absent from whole-cell hydrolysates. Urease and Diazonium blue $\mathrm{B}$ reactions are positive. The major ubiquinone is Q-10. The $\mathrm{G}+\mathrm{C}$ content of the DNA is $66-68 \mathrm{~mol} \%$, as determined by HPLC. The type strain is ATCC $36489^{\mathrm{T}}=\mathrm{CBS} 544.50^{\mathrm{T}}=\mathrm{JCM} 8362^{\mathrm{T}}$.

\section{Emended description of Tilletiopsis cremea Tubaki}

Characteristics additional to the description of Tubaki 1952 of this species are given below.

Assimilates D-glucose, galactose, sucrose, maltose, cellobiose (variable), trehalose, melibiose (variable), raffinose, melezitose, soluble starch, D-xylose, L-arabinose, D-arabinose, D-ribose, ethanol (variable), glycerol, erythritol, ribitol (variable), D-mannitol, Dglucitol, methyl $\alpha$-D-glucoside (variable), glucono- $\delta$ lactone (variable), DL-lactic acid, succinic acid and citric acid. Does not assimilate L-sorbose, lactose, inulin, L-rhamnose, galactitol, salicin, 2-ketogluconic acid, 5-ketogluconic acid, inositol or D-glucuronic acid. Assimilates nitrate, nitrite and L-lysine (variable). Does not assimilate ethylamine or cadaverine. Growth does not occur in vitamin-free medium. Thiamin is required for growth. Growth does not occur on $50 \%$ (w/w) glucose/yeast extract agar. No starch-like substance is produced. Xylose is absent from whole-cell hydrolysates. Urease and Diazonium blue B reactions are positive. The major ubiquinone is $\mathrm{Q}-10$. The $\mathrm{G}+\mathrm{C}$ content of the DNA is $67 \mathrm{~mol} \%$, as determined by HPLC. The type strain is CBS $605.83^{\mathrm{T}}=\mathrm{IFO} 6831^{\mathrm{T}}$ $=\mathrm{JCM} 5184^{\mathrm{T}}$.

\section{Emended description of Tilletiopsis lilacina Tubaki}

Characteristics additional to the description of Tubaki 1952 of this species are given below.

Assimilates D-glucose, galactose, L-sorbose (variable), sucrose, maltose, cellobiose (variable), trehalose, melibiose, raffinose, melezitose, soluble starch, D-xylose, Larabinose, D-arabinose (variable), D-ribose, ethanol (variable), glycerol, erythritol, ribitol (variable), Dmannitol, D-glucitol, methyl $\alpha$-D-glucoside (variable), salicin (variable), glucono- $\delta$-lactone (variable), DLlactic acid (variable), succinic acid and citric acid. Does not assimilate lactose, inulin, L-rhamnose, galactitol, 2-ketogluconic acid, 5-ketogluconic acid, inositol or D-glucuronic acid. Assimilates nitrate, nitrite and Llysine (variable). Does not assimilate ethylamine or cadaverine. Growth does not occur in vitamin-free medium. Thiamin is required for growth. Growth does not occur on $50 \%(\mathrm{w} / \mathrm{w})$ glucose/yeast extract agar. No starch-like substance is produced. Xylose is absent from whole-cell hydrolysates. Urease and Diazonium blue $\mathrm{B}$ reactions are positive. The major ubiquinone is $\mathrm{Q}-10$. The $\mathrm{G}+\mathrm{C}$ content of the DNA is $67-68 \mathrm{~mol} \%$, as determined by HPLC. The type strain is CBS $435.92^{\mathrm{T}}=$ CBS $603.83^{\mathrm{T}}=$ IFO $6832^{\mathrm{T}}=\mathrm{JCM} 5188^{\mathrm{T}}$.

\section{REFERENCES}

Berbee, M. L., Yoshimura, A., Sugiyama, J. \& Taylor, J. W. (1995). Is Penicillium monophyletic? An evaluation of phylogeny in the family Trichomaceae from $18 \mathrm{~S}, 5 \cdot 8 \mathrm{~S}$ and ITS ribosomal DNA sequence data. Mycologia 87, 210-222.

Boekhout, T. (1991). A revision of ballistoconidia-forming yeasts and fungi. Stud Mycol 33, 1-194.

Boekhout, T. (1998). Tilletiopsis Derx et Derx. In The Yeasts, a Taxonomic Study, 4th edn, pp. 848-853. Edited by C. P. Kurtzman \& J. W. Fell. Amsterdam: Elsevier.

Boekhout, T., van Gool, J., van den Boogert, H. \& Jille, T. (1992a). Karyotyping and $\mathrm{G}+\mathrm{C}$ comparison as taxonomic criteria applied to the systematics of Tilletiopsis and related taxa. Mycol Res 96, 331-342.

Boekhout, T., Yamada, Y., Weijman, A. C. M., Roeijmans, H. J. \& Batenburg-van der Vegte, W. H. (1992b). The significance of coenzyme Q, carbohydrate composition and septal ultrastructure for the taxonomy of ballistoconidia-forming yeasts and fungi. Syst Appl Microbiol 15, 1-10.

Derx, H. G. (1930). Etude sur les Sporobolomycètes. Ann Mycologici 28, 1-23.

Derx, H. G. (1948). Itersonilia, nouveau genre de Sporobolomycètes à mycélium bouclé. Bull Bot Garden Buitenzorg (Series III) 17, 465-472.

Felsenstein, J. (1985). Confidence limits on phylogenies: an approach using the bootstrap. Evolution 39, 783-791.

Felsenstein, J. (1995). PHYLIP (phylogeny inference package), version 3.57c. Department of Genetics, University of Washington, Seattle, WA, USA.

Gokhale, A. A. (1972). Studies on the genus Tilletiopsis. Nova Hedwigia 23, 795-809.

Hamamoto, M. \& Nakase, T. (1995). Ballistosporous yeasts found on the surface of plant materials collected in New Zealand. 1. Sporobolomyces. Antonie Leeuwenhoek 67, 151-171.

James, S. A., Collins, M. D. \& Roberts, I. N. (1996). Use of an rRNA internal transcribed spacer region to distinguish phylogenetically closely related species of the genera Zygosaccharomyces and Torulaspora. Int J Syst Bacteriol 46, 189-194.

Nagahama, T., Hamamoto, M., Nakase, T. \& Horikoshi, K. (1999). Kluyveromyces nonfermentans sp. nov., a new yeast species isolated from the deep sea. Int J Syst Bacteriol 49, 1899-1905.

Nakase, T. \& Suzuki, M. (1986). Bullera megalospora, a new species of yeast forming large ballistospores isolated from dead leaves of Oryza sativa, Miscanthus sinensis and Sasa sp. in Japan. J Gen Appl Microbiol 32, 225-240.

Nyland, G. (1950). The genus Tilletiopsis. Mycologia 42, 487-496. Oda, Y., Yabuki, M., Tonomura, K. \& Fukunaga, M. (1997). Reexamination of yeast strains classified as Torulaspora delbrueckii (Lindner). Int J Syst Bacteriol 47, 1102-1106.

Saitou, N. \& Nei, M. (1987). The neighbor-joining method: a new 
method for reconstructing phylogenetic trees. Mol Biol Evol 4, 406-425.

Thompson, J. D., Higgins, D. G. \& Gibson, T. J. (1994). CLUSTAL $\mathrm{W}$ : improving the sensitivity of progressive multiple sequence alignment through sequence weighting, position-specific gap penalties and weight matrix choice. Nucleic Acids Res 22, 4673-4680.

Tubaki, K. (1952). Studies on the Sporobolomycetaceae in Japan. I. On Tilletiopsis. Nagao 1, 26-31.

Waalwijk, C., de Koning, J. R. A., Baayen, R. P. \& Gams, W. (1996). Discordant groupings of Fusarium spp. from sections Elegans, Liseola and Dlaminia based on ribosomal ITS1 and ITS2 sequences. Mycologia 88, 361-368. van der Walt, J. P. \& Yarrow, D. (1984). Methods for isolation, maintenance, classification and identification of yeasts. In The Yeasts, a Taxonomic Study, 3rd edn, pp. 45-104. Edited by N. J. W. Kreger-van Rij. Amsterdam: Elsevier.

White, T., Bruns, T., Lee, S. \& Taylor, J. W. (1990). Amplification and direct sequencing of fungal ribosomal RNA genes for phylogenetics. In PCR Protocols, pp. 315-322. Edited by M. A. Innis, D. Gelfand, J. J. Sninsky \& T. J. White. San Diego: Academic Press.

Yamazaki, M., Goto, S. \& Komagata, K. (1985). Taxonomical studies of the genus Tilletiopsis on physiological properties and electrophoretic comparison of enzymes. Trans Mycol Soc Jpn 26, 13-22. 